\title{
Child Development: An Overview for the busy psychiatrist
}

\author{
Dinesh Saroj \\ Neurodevelopmental Paediatrician, Fellowship in Learning Disabilities and Neurodevelopmental Paediatrics, \\ Lokmanya Tilak Municipal Medical College and General Hospital, Mumbai \\ Corresponding author: Dinesh Saroj \\ Email-dnshsaroj@gmail.com
}

\begin{abstract}
Child Development and milestones are vital aspects of history taking when it comes to child and adolescent psychiatry. The article here aims to provide the psychiatrist an overview of child development and various milestones and the age at which they are achieved. The article aims to give the clinician details of these milestones as applicable in clinical practice and enables the clinician to use the same in history and assessment of children and adolescents with psychological problems.
\end{abstract}

Keywords: children, development, child development.

(Paper received $-30^{\text {th }}$ April 2019, Peer review completed $-2^{\text {nd }}$ June 2019)

(Accepted - 10 ${ }^{\text {th }}$ June 2019)

\section{INTRODUCTION}

Development involves a persistent change and acquisition of different skills for optimal functionality in a social environment. It is a continuous process from birth to maturity. Growth indicates overall well-being and status of chronic diseases. The knowledge of normal growth, development and behaviour is significant to effectively monitor child's progress. It helps to identify delays or abnormalities in development and counsel parents and caretakers, thereby optimize the growth and development of each child. It helps to understand how mutual forces interact within the parent-child relationship, within the family and between the family and society at large. A thorough knowledge and understanding of the normal development is very much crucial to anyone concerned with the care of children. Growth and development have been a traditional "concern" of primary health care providers. Family physicians, Paediatricians and Psychiatrists must know the normal and its variations before one can identify the abnormalities.

Developmental delay is when a child exhibits significant delay in the acquisition of milestones in one or more domains of development- gross and fine motor; speech and language; cognition; personal and social development or in activities of daily living. Global developmental delay can be defined as significant delay in two or more developmental domains. Delay is said to be significant with discrepancy of $25 \%$ or more from the expected rate or a discrepancy of 1.5 to 2 standard deviations from the norm. The extent of delay can be classified as mild if functional age is $33 \%$ below chronological age, moderate if functional age is 34$66 \%$ of chronological age, and severe if functional age is $66 \%$ below chronological age.

A child with the clinical picture of global developmental delay is not necessarily destined to have intellectual disability. Deviance occurs when a child acquires milestones outside of the typical sequence as in cerebral palsy in which the infant rolls over early secondary to increased extensor tone.

When a child displays widely differing rates of development in different developmental domains, it is termed as 'Dissociation'. For example, children with Autism Spectrum Disorder have typical gross motor 
development but significantly delayed language development. 'Developmental Regression' occurs when a child loses already acquired skills or milestones. It is often associated with inherited metabolic disorders and serious neurological problems.

Developmental disorders include a wide range of conditions that result from physical and / or cognitive impairments. They are mostly reported by parents and school teachers in the developmental period of the child. These problems are related to delayed milestones, inappropriate feelings, unsatisfactory interpersonal relationships, school learning problems, physical symptoms or fears related to problems at school. The focus on developmental-behavioural issues reflect changing priorities in traditional health care for children and helps consolidate a distinct fund of medical knowledge.

\section{NORMAL DEVELOPMENT}

Development as a phenomenon represents the progression towards maturity- physical and mental. Often the terms 'Growth and Development' are used together. Growth is increase in size and is measured using physical parameters. Development is a continuous and multi-faceted process by which child achieves competency to perform complex activities and tasks. It can be sub-divided into:

1. Physical Development: acquisition of gross and fine motor skills

2. Language Development: transition from vocalization to understanding and use of language for communication.

3. Cognitive Development: acquisition of mental abilities such as learning, memory, concrete thinking and abstract reasoning.

4. Social and Emotional Development: establishing the pattern of behaviour and way of dealing with others.

A thorough knowledge of the normal development forms an underlying base of the study of abnormality. At the same time, one should also be conversant with the normal variations, not amounting to disease.

\section{THE PRINCIPLES OF NORMAL DEVELOPMENT}

The principles of normal development can be summarized as follows:

1. Development is a continuous process starting from stage of conception until maturity. The process of development starts in- utero and continues after birth.

2. The sequence of development is the same in all children. It is the rate of development that varies from child to child. For example, a child has to learn to sit before he can learn to walk. However, the age at which children learn to sit and to walk differs widely.

3. Development is closely related to the maturation of the nervous system. For instance, a child can learn to walk only when his nervous system is ready for it.

4. Specific individual behavioural responses come in place of generalized activity. For instance, a young infant excitedly moves his trunk, arms and legs when he sees something interesting whereas the older infant merely smiles and reaches out for the same.

5. Development progresses in the cephalocaudal direction. The development of head control is a preliminary step before learning to walk without support. The infant can manipulate his hands before he can walk.

6. The primitive reflexes, such as walking reflex, have to be lost before the corresponding voluntary movement is picked up.

\section{FACTORS INFLUENCING CHILD DEVELOPMENT}

Adaptation to one's surrounding environment and prevalent culture is essential for normal development of the child. Environment at home, neighbourhood and school has a profound influence on a child's potentials. Both child's biological endowment and learning experiences are important in the complex 
processes of child development and behaviour. Nature and nurture are intimately and intricately intermingled, and are inseparable. The age of the mother \& father are amongst the pre-natal factors that affect child development. Cerebellum begins to grow later than the rest of the brain but completes its growth sooner and poverty along with poor maternal nutrition during pregnancy negatively impacts interneuronal connections inside the cerebellum. Late preterm infants have poorer neurodevelopmental outcomes compared to term infants.

\section{THE PARAMETERS OF DEVELOPMENT}

Parameters of development include the below-mentioned:

1. Physical growth

2. Motor development- gross and fine motor, balance and movement

3. Language and communication development

4. Adaptive (Non-verbal) development

5. Personal-social development

6. Hearing and vision

\section{MILESTONES}

They are a set of functional skills or age specific tasks that most children can do in a certain age range. Taking into account individual variability in child's development, a normal age range is given on milestone checklists. They help to check how a child is developing. Using milestones as the sole method for assessing development is not recommended because of its potential inaccuracy. Thus, parental recall of milestones is demonstrated to be less accurate. However, knowing the appropriate milestones is a key to good history taking. Reliability of the measure increases when milestones are significantly delayed. Written questionnaires are preferable to asking questions during a consultation.

\section{PHYSICAL GROWTH}

Physical growth is the most apparent change during infancy. Apart from growth, many organs acquire maturity and functionality in terms of multiplication of cells and pattern formation. The important parameters of physical growth include weight, height and head circumference. At birth, mid-brain is the most developed part of the brain. Cortex acquires dominance by 6 months of age resulting in disappearance of some primitive reflexes. Areas of brain responsible for hearing and vision are well developed at birth. Gross motor development follows thereafter while higher cognitive functions come later, after birth.

\section{GROSS MOTOR DEVELOPMENT}

Gross motor development implies various milestones related to sitting, standing, crawling and walking. These developments are closely related with maturation of the brain. Hence, the ability to move erect and letting the limbs move across the body's midline is the result of a balance between flexor and extensor tone, diminution of obligatory primary reflexes and evolution of protective and equilibrium responses. When the newborn baby is pulled to the sitting position, there is complete head lag. When half pulled up, he or she will raise the head. The back is uniformly rounded, when in sitting position. The head lag decreases with maturation, so that by 12 weeks it is only slight and an infant gains head control by 28 weeks, raising it spontaneously off the couch and repeatedly. Also, by 24 weeks, when made to sit, he / she can sit propped up with straight back. After a month or so, the infant sits on the floor with arms forward for support. By 40-44 weeks he / she can sit steady and can manipulate objects at hand. The infant can sit by the self in a chair by 15 months.

$\mathrm{He} /$ she can bear all his weight by 24 weeks. At 36 weeks, they stand holding on to furniture and can pull themselves up to the standing position, but cannot let them-self down. At 44 weeks the infant can lift one foot off the ground and can walk holding on to the table at 48 weeks. At 13 months, he / she can walk without any support. At 15 months, the infant starts to creep upstairs. Also, the infant can get into the standing position independently. At 18 months, he / she can walk up and down stairs without help. At 2 
years they can pick up an object on the floor, without falling, can run and walk backward. They go up and down stairs with two feet per step. At three the infant can balance self on one leg for a few seconds. He / she can go upstairs one foot per step, and downstairs two feet per step and can ride a tricycle. At four, he / she can go downstairs one foot per step and also learns to skip on one foot. At six, the infant can skip on both feet.

\section{FINE MOTOR DEVELOPMENT}

The disappearance of the certain primitive reflexes and acquisition of accommodative abilities between 2 and 3 months of age allow infants to look at their hands and touch one hand with the other furnishing simultaneous information to the senses of vision and touch, and thereby, provides a foundation for later visual motor skills.

Between 2 and 3 months of age, infants look at their hands and join them together. As visual acuity improves, infants begin swiping at objects in front of respective shoulder. By 6 months of age, they reach persistently toward objects in the midline, at first with both hands and then with one. By 40 weeks, they can pick up a small object using finger and thumb together. By 13 months, they can build a tower of two 1inch cubes and by 15 months, they can pick up a cup and drink from it without spilling much. At 18 months, the infants can turn two or three pages of a book at a time; they learn to turn them singly by the time they reach the age of 2 years. By $2 \frac{1}{2}$ years, they can thread beads, and by 3 years, the infants can build a tower of 10 cubes, draw and paint. They learn to fasten buttons, dress and undress themselves.

\section{LANGUAGE AND COMMUNICATION DEVELOPMENT}

Infants communicate with their mother by smiling, laughing, screaming, throwing temper tantrums, vocalizing and by watching her as she speaks. They vocalize one word with meaning by 10 months of age. The infant responds to 'No' and obeys orders, waves bye-bye and plays pat-a-cake. The child grasps jargons by 15 to 18 months. In most cases, they intend to ask 'wh' questions. They also achieve grammatical correctness gradually as they talk. At 2 years, they understand two-step commands while at 35 years, they tend to answer "wh" questions.

\section{SOCIAL /ADAPTIVE DEVELOPMENT}

Most of the children express their readiness for toileting between the ages of 18 and 24 months which is evident by interest in sitting at the toilet seat, ability to get to the toilet and pull down pants, and having a word for urination and stooling, dislike of being soiled or wet. Voluntary control of micturition begins after 15-18 months of age. Most children are reasonably dry by day at 18 months. Toilet training is generally accomplished by 3 years. The day time bladder control is achieved earlier as compared to night time control. In general, pre-schoolers display behavioural problems like nightmares, night terrors, sleepwalking, or sleep talking. There occurs dramatic slowing of rate of growth amongst pre-schoolers making them selective with their dietary choices. It signifies their emerging sense of self.

\section{SENSORY AND MOTOR MATURATION}

Infants need to actively coordinate- (1) Level of arousal, (2) Sensory stimuli and (3) Voluntary control of fine and gross motor movements to learn about social and inanimate world. During early infancy, certain neurophysiologic and neuroanatomic changes allow to regulate the state of arousal and along with mutual regulation with the caregiver, it forms the basis of social and emotional development.

\section{SOCIAL-EMOTIONAL DEVELOPMENT}

Psychosocial and Emotional development is characterized by a distinct blend of increased self-respect and freedom with increased social emotional reciprocity and self-awareness. Young pre-schoolers display multitude of emotions without an ability to regulate them resulting in impulsive reactions. This manifests as behavioural acting out (e.g. temper tantrums) or emotional sensitivity. A sense of pride is reflected in every new tasks and celebration in even little achievements. Late pre-schoolers are able to execute basic but effective coping strategies successfully. 


\section{COGNITIVE DEVELOPMENT}

\section{Jean Piaget's Theory of Cognitive Development}

This theory provides a valuable guidance about cognitive development in an infant. A central ideology of Piaget's work is that cognition changes in quality as well as quantity.

According to this theory, infants are active learners as they modify their behaviour in response to environmental needs. They integrate information and also accommodate themselves to environmental responses called as 'schemas'.

When faced with a novel situation, the infant can create a new or change an existing schema to "accommodate" or "assimilate" the new information. These adaptations, across different stages lead eventually to maturity.

Cognitive development during the sensorimotor period (birth to 2 years of age) can be organized into six stages. Each stage represents a temporary equilibrium between the infant's skills and the environment's challenges.

1. Birth to one month: reflex actions which may be modified by experience

2. One to four months: active movements of body to produce new situations

3. Four to ten months: concept of environment and self as exclusive and relation of body actions with objects.

4. Ten to twelve months: uses discovered strategies of the body to create known and new situations.

5. Twelve to eighteen months: formulates new strategies and manipulates objects

6. Eighteen to twenty four months: uses concepts to achieve desired results.

Pre operational thought stage from two to six years: Seeing things from someone else's viewpoint is difficult. Child cannot understand constancy and permanency of objects.

Concrete operational stage from six to twelve years: Memory and logical thinking is helped by the child's ability to add learnt concepts to his thinking process like mathematics, reading.

Formal operational stage, above twelve years: Abstract thought develops. Power of deduction emerges.

\section{Erikson's Psychoanalytical Theory}

According to this theory, the child's sense of basic trust develops through the successful negotiation of infantile needs. A toddler will be engaged with thoughts of acquiring autonomy while a late-adolescent on establishing meaningful relationships.

\section{TABLE 1 - DEVELOPMENTAL MILESTONES IN FIRST 5 YEARS OF LIFE AS PER DEVELOPMENTAL DOMAINS}

\begin{tabular}{|l|l|l|l|l|}
\hline Age & Gross Motor & Fine Motor & Language & Social/Adaptive \\
\hline $\mathbf{1}$ month & $\begin{array}{l}\text { Lifts head when } \\
\text { prone }\end{array}$ & $\begin{array}{l}\text { Visually fixes to } \\
\text { midline }\end{array}$ & Vocalizes & $\begin{array}{l}\text { Regards faces, } \\
\text { social smile at } 6 \\
\text { wks }\end{array}$ \\
\hline $\mathbf{2}$ months & $\begin{array}{l}\text { Holds head steady } \\
\text { while sitting, Can } \\
\text { lift head } 45^{\circ} \text { and } \\
\text { extend arms } \\
\text { forward } \\
\text { when prone }\end{array}$ & $\begin{array}{l}\text { Can follow across } \\
\text { midline, grabs } \\
\text { clothes }\end{array}$ & $\begin{array}{l}\text { Coos, Smiles in } \\
\text { response to face, } \\
\text { voice }\end{array}$ & $\begin{array}{l}\text { Social smile, Stares } \\
\text { momentarily at } \\
\text { spot where object } \\
\text { disappeared }\end{array}$ \\
\hline $\mathbf{3}$ months & $\begin{array}{l}\text { Pulls to sit, with } \\
\text { no head lag, Brings } \\
\text { hands together in } \\
\text { midline }\end{array}$ & Grasps rattle & & \\
\hline
\end{tabular}




\begin{tabular}{|c|c|c|c|c|}
\hline 4 months & $\begin{array}{l}\text { Can raise head and } \\
\text { chest when prone, } \\
\text { no } \\
\text { head lag, rolls } \\
\text { front } \\
\text { to back }\end{array}$ & $\begin{array}{l}\text { Hands together, } \\
\text { objects to mouth, } \\
\text { Reaches for } \\
\text { objects, Palmar } \\
\text { grasp gone }\end{array}$ & $\begin{array}{l}\text { Responds to voice, } \\
\text { squeals }\end{array}$ & Stares at own hand \\
\hline 6 months & $\begin{array}{l}\text { Sits without } \\
\text { support }\end{array}$ & $\begin{array}{l}\text { Reaches for toys, } \\
\text { ulnar grasp } \\
\text { Transfers across } \\
\text { midline }\end{array}$ & $\begin{array}{l}\text { responds to } \\
\text { name, imitates } \\
\text { sounds, } \\
\text { Monosyllabic } \\
\text { babble }\end{array}$ & Stranger anxiety \\
\hline 8 months & $\begin{array}{l}\text { Can stand if held, } \\
\text { Crawls, pulls to a } \\
\text { stand }\end{array}$ & $\begin{array}{l}\text { Thumb-finger } \\
\text { grasp }\end{array}$ & $\begin{array}{l}\text { Mama/dada } \\
\text { (nonspecific), } \\
\text { Inhibits to "no" } \\
\text { Follows one-step } \\
\text { command with } \\
\text { gesture }\end{array}$ & $\begin{array}{l}\text { Waves bye-bye at } \\
8.5 \text { months, Bangs } \\
2 \text { cubes, Uncovers } \\
\text { toy (after seeing it } \\
\text { hidden) }\end{array}$ \\
\hline 9 months & Cruises & & Jabbers & Plays patty-cake \\
\hline 10 months & $\begin{array}{l}\text { Cruises at } 11 \\
\text { months }\end{array}$ & Pincer grasp & $\begin{array}{l}\text { Mama/dada } \\
\text { (specific), Points } \\
\text { to objects, Follows } \\
\text { one-step command } \\
\text { without gesture }\end{array}$ & Plays peek-a-boo \\
\hline 12 months & $\begin{array}{l}\text { Walks alone or } \\
\text { with } \\
\text { support }\end{array}$ & $\begin{array}{l}\text { Throws, Turns } \\
\text { pages of book }\end{array}$ & $\begin{array}{l}\text { Few words plus } \\
\text { mama/dada Speaks } \\
\text { first real word }\end{array}$ & $\begin{array}{l}\text { Drinks from a cup, } \\
\text { Egocentric } \\
\text { symbolic play (e.g., } \\
\text { pretends to drink } \\
\text { from cup) }\end{array}$ \\
\hline 15 months & $\begin{array}{l}\text { Walks well, walks } \\
\text { backwards }\end{array}$ & $\begin{array}{l}\text { Scribbles, can } \\
\text { make tower of } 2-3 \\
\text { cubes }\end{array}$ & $\begin{array}{l}\text { Points, follows } \\
\text { simple commands }\end{array}$ & $\begin{array}{l}\text { Hugs parents, uses } \\
\text { spoon/fork, } \\
\text { removes clothes }\end{array}$ \\
\hline 18 months & $\begin{array}{l}\text { Runs, walks } \\
\text { upstairs, } \\
\text { kicks ball }\end{array}$ & Tower of $3-4$ cubes & Knows 10 words & $\begin{array}{l}\text { Feeds self, helps } \\
\text { brush teeth, pts to } \\
\text { body parts, Uses } \\
\text { stick to reach toy }\end{array}$ \\
\hline 2 years & $\begin{array}{l}\text { Runs well, Walks } \\
\text { up and down } \\
\text { Stairs } 1 \text { step at a } \\
\text { time, opens doors, } \\
\text { climbs on } \\
\text { furniture, throws a } \\
\text { ball } \\
\text { overhead, jumps }\end{array}$ & $\begin{array}{l}\text { Initiates pencil } \\
\text { stroke, tower of } 6 \\
\text { cubes }\end{array}$ & $\begin{array}{l}2-3 \text { word phrases, } \\
25 \% \text { of speech } \\
\text { understandable }\end{array}$ & $\begin{array}{l}\text { Listens to stories, } \\
\text { parallel play }\end{array}$ \\
\hline 2.5 years & Walks on toes & Tower of 8 cubes & $\begin{array}{l}\text { Knows name, } 50 \% \\
\text { of speech } \\
\text { understandable }\end{array}$ & $\begin{array}{l}\text { Dry at night, toilet } \\
\text { trained between 2- } \\
3 \text { yrs }\end{array}$ \\
\hline 3 years & $\begin{array}{l}\text { Rides tricycle, } \\
\text { Goes up stairs with } \\
\text { alternating feet, } \\
\text { stands on one foot } \\
\text { momentarily }\end{array}$ & $\begin{array}{l}\text { Imitates } \\
\text { construction of } \\
\text { bridge of } 3 \text { cubes, } \\
\text { Copies a circle and } \\
\text { imitates a cross }\end{array}$ & $\begin{array}{l}3 \text { word phrases, } \\
\text { knows age and } \\
\text { gender, } 75 \% \text { of } \\
\text { speech } \\
\text { understandable }\end{array}$ & $\begin{array}{l}\text { Plays with others, } \\
\text { shares toys, } \\
\text { partially dresses } \\
\text { self }\end{array}$ \\
\hline
\end{tabular}




\begin{tabular}{|l|l|l|l|l|}
\hline 4 years & $\begin{array}{l}\text { Hops on one foot, } \\
\text { throws ball } \\
\text { overhand, cuts out } \\
\text { pictures with the } \\
\text { help of scissors }\end{array}$ & $\begin{array}{l}\text { Copies a square } \\
\text { and a cross, } \\
\text { uses scissors, } \\
\text { draws a man with } \\
\text { 2-4 parts besides } \\
\text { head, can identify } \\
\text { longer of the two } \\
\text { lines }\end{array}$ & $\begin{array}{l}\text { Tells a story, asks } \\
\text { questions, knows } \\
\text { full name, 90\% of } \\
\text { speech } \\
\text { understandable }\end{array}$ & $\begin{array}{l}\text { Interactive play, } \\
\text { role play, } \\
\text { dresses } \\
\text { self completely, } \\
\text { brushes teeth on } \\
\text { own }\end{array}$ \\
\hline $\mathbf{5}$ years & $\begin{array}{l}\text { Rides a bike } \\
\text { with training } \\
\text { wheels, Skips. }\end{array}$ & $\begin{array}{l}\text { Copies a triangle, } \\
\text { ties shoes, names } \\
\text { heavier of the two } \\
\text { weights, prints } \\
\text { name, draws a } \\
\text { person (6 parts) }\end{array}$ & Names 4 colors & $\begin{array}{l}\text { Fluent speech, } \\
\text { goes to } \\
\text { toilet alone, can } \\
\text { say alphabet } \\
\text { Plays competitive } \\
\text { games with rules }\end{array}$ \\
\hline
\end{tabular}

\section{THE DEVELOPMENTAL HISTORY}

A history of prenatal and perinatal factors is most relevant to the understanding of the child's development. A detailed history from conception to the present must be sought. It must include the 'risk factors' for cognitive and physical development, for disabilities like - blindness, deafness, subluxation of the hip, cerebral palsy, intellectual disability and genetic conditions, such as degenerative disease of the nervous system, schizophrenia and manic-depressive psychoses.

While calculating test performance appropriate to a child's age, a baby born low birth weight appropriate for gestation must be distinguished from the baby who was small-for-date so as to decide whether or not to account for the prematurity. The history must include environmental factors which affect development like the rate of development, the familial pattern of development, the amount of exposure, emotional deprivation, parent- child interaction, child abuse, and malnutrition. The mother's observations must be taken into consideration to supplement history of achievements. It is useful to determine whether one's own assessment tallies with the mother's inputs of the child's development.

\section{DEVELOPMENTAL AND BEHAVIOURAL SURVEILLANCE AND SCREENING}

Developmental screening is the administration of brief, standardized, formal tool for identification of children at a risk for developmental disorders. In contrast, developmental surveillance is defined as a flexible, longitudinal, continuous, and cumulative process for identifying children who may have developmental problems and is performed at every well-child visit. Surveillance through proper history and physical examination should occur at every well-child visit. Primary care clinicians often use informal techniques that are usually weak in reliability and validity, to identify developmental delays or behavioural problems resulting in under-referral of children. Clinicians must know the standardized assessment measures with appropriate levels of specificity and sensitivity that can either be self-administered in waiting or examination rooms or administered online before an appointment.

As per American Academy of Paediatrics (AAP), a good screening tool is the one with sensitivity and specificity in the $70-80 \%$ range. It is meant to suggest 'at risk' children and not for making diagnoses. It should be done by a centre that provides medical services to the family. Evidence-based care has shown significant improvements in a child with special health care needs. The principle followed is the same as used in other health conditions. The use of standardized tools over an informal judgement is highly recommended for detection of the degree of abnormality of a child's behaviour and development. It helps the caregiver to discuss age matched activities and provide developmentally appropriate opportunities. Those children who could not pass the screening test should be followed up closely and subjected to additional assessment by means of early intervention referral. "wait and see" approach is strongly 
condemned. Considering the fact that isolated developmental delay is seen in less than $1 \%$, only those children with relevant history or physical examination should be subjected to metabolic screening.

Assessing milestones is a challenge in pre-schoolers complicating the task of screening them for developmental delay. The most likely areas of developmental concern to be identified in pre-schoolers are delays in expressive or receptive language skills, fine motor or gross motor coordination skills and rate of acquisition of early learning concepts. The American Academy of Paediatrics recommends that screening for developmental delay should occur at least three times at well-care visits for children between infancy and age 3 years. Obstacles for successful and wide spread implementation of screening tools include time, expertise and awareness of significance of early identification and intervention. Referral is indicated for any child about whom the parents have voiced a concern. An expert is likely to assess development of only referred children. Hence a rough developmental screening should be scheduled in each infant and young child visit.

\section{DEVELOPMENTAL PREDICTION}

One should be familiar with the limits of developmental assessment before commencing to assess development. It is only with great difficulty that one can differentiate between normal and abnormal in the early infancy. The profound effect of environmental and other factors in future makes it difficult to predict intelligence of the child accurately only on the basis of developmental assessment in infancy

\section{EARLY INTERVENTION}

Early intervention is targeted at providing well defined opportunities to develop, providing special services to children and their families and to practice skills appropriate to child's developmental level. It should aim for an all-round development. An active coordination between the health care professionals and local early intervention programs is essential to encourage and facilitate the optimal development of children. Early intervention results in improved outcomes in most of the children. Different health care professionals can train parents about how to provide early intervention.

\section{REGULATORY ISSUES}

Toilet training, eating and sleeping are the most commonly sought regulatory issues by parents. High level of understanding and patience is required on behalf of parents. It is always advisable to issue written advice for parents and clinicians are expected to remain up to date regarding what parents are reading.

\section{ADVISING ON KINDERGARTEN READINESS}

Motor abilities, language development and pre-academic or academic skills constitute assessments for kindergarten readiness. Also, the domains like child's attention, social abilities, self-regulation predicts success in school. These are more difficult to assess than pre-academic and motor abilities. Child should be encouraged to know his or her telephone number and address for his safety.

\section{CONCLUSION}

The current challenge faced by the primary health care professionals is to identify developmental and behavioural disorders in children in the course of providing health care to them. This can be made possible by means of universal health care concepts of surveillance, screening and evaluation. A strict vigilance on behalf of primary health care provider is expected for identifying those children who require further evaluation and referral. A systematic and algorithmic approach can help in early identification and ongoing monitoring of a child's development. A standardized objective screening tests with acceptable levels of sensitivity and specificity should be used in this regard. A clinician-guided, systematic approach 
can help in its successful implementation. The child identified with developmental or behavioural concerns can begin the process of diagnostic evaluation and subsequently, begin treatment for the identified conditions. A change in the approach of primary care clinicians towards families is essential to make early intervention a reality.

\section{RECOMMENDED READING}

1. Ainsworth MD, Blehar MC, Waters E, Wall S. Patterns of attachment. Lawrence Hillsdale; 1992.

2. Aro H, Taipale $\mathrm{V}$. The impact of timing of puberty on psychosomatic symptoms among fourteen-to sixteenyear-old Finnish girls. Child Dev 1987;1:261-8.

3. Gopnik A. Cognitive development: domains and theories. Nelson Textbook of Pediatrics. 20th ed. Philadelphia, PA: Elsevier. 2016.

4. Carey WB, Crocker AC, Elias ER, Feldman HM, Coleman WL. Developmental-Behavioral Pediatrics EBook. Elsevier Health Sciences; 2009.

5. Illingworth RS. Environmental Factors and Development. In: Russell P, Nair MKC, editors. The Development of the Infant and Young Child Normal and Abnormal. 20th edition. New Delhi: Elsevier, 2012; p. 47-68

6. Illingworth RS. Prenatal and Perinatal Factors Relevant to Developmental Assessment and Diagnosis. In: Russell P, Nair MKC, editors. The Development of the Infant and Young Child Normal and Abnormal. 20th edition. New Delhi: Elsevier, 2012; p. 19-46.

7. Majnemer A, Shevell MI. Diagnostic yield of the neurologic assessment of the developmentally delayed child. J Pediatr 1995;127(2):193-9.

8. McDonald L, Rennie A, Tolmie J, Galloway P, McWilliam R. Investigation of global developmental delay. Arch Dis Childhood 2006;91(8):701-5.

9. Olness K. Self-control and self-regulation: normal development to clinical conditions. In Developmentalbehavioral pediatrics 2009 Jan 1 (pp. 453-459). WB Saunders.

10. Poon JK, Larosa AC, Pai GS. Developmental delay: timely identification and assessment. Indian Pediatr 2010;47(5):415-22.

11. Shevell MI, Ashwal S, Donley D, Flint J, Gingold M, Hirtz D, Majnemer A, Noetzel M, Sheth RD. Practice parameter: evaluation of the child with global developmental delay: report of the Quality Standards Subcommittee of the American Academy of Neurology and The Practice Committee of the Child Neurology Society. Neurology 2003;60(3):367-80.

12. Waters E, Wippman J, Sroufe LA. Attachment, positive affect, and competence in the peer group: Two studies in construct validation. Child Dev 1979;1:821-9.

13. Wang P. Nature, nurture and their interactions in child development and behavior. Dev Behav Pediatr 2011;1:5-21.

14. Vora $\mathrm{H}$, Shah $\mathrm{P}$, Mansuri SH. A study on developmental delay among children less than 2 year attending well baby clinic-Prevalence and antecedent factors. Int J Med Sci Public Health 2013;2(4):1084.

15. Santrock JW. Child development. New York: McGrow. 2007.

16. Schaffer HR. Introducing child psychology. Blackwell Publishing; 2004.

17. Hurlock EB. Developmental psychology. Tata McGraw-Hill Education; 2001.

$$
\begin{gathered}
\text { Acknowledgements - Nil } \\
\text { Source of Funding - Nil } \\
\text { Conflict of Interest - Nil }
\end{gathered}
$$

